Оригинални научни рад

János Ede Szilágyi, Ph.D., Associate Professor

University of Miskolc

Faculty of Law

civdrede@uni-miskolc.hu

\title{
CROSS-BORDER ACQUISITION OF THE OWNERSHIP OF AGRICULTURAL LANDS AND SOME TOPICAL ISSUES OF THE HUNGARIAN LAW
}

\begin{abstract}
While Serbia is working on a new EU-conform land law, the EU law concerning the cross-border acquisition of agricultural lands cannot be considered as a static phenomenon. Namely, the issue is quite controversial among the EU's institutions and Member States. Evidence of this is the high number of infringement procedures launched by the EU Commission against the Member States joined the EU in 2004 or afterwards (hereinafter referred to as New Member States). However, it is worth stressing that the debate is not merely a New-MemberState-issue but a general one, and there are numerous uncertainties which may affect even the old Member States' land law regimes. That is the reason (or one of the most important reasons) why the European Parliament adopted a report on the state of play of farmland concentration in the EU in 2017. It seems that nowadays land issues have also become one of the topical questions of the EU, which questions could be raised because the EU is in a kind of the crisis. The EU should redefine itself and its goals, furthermore, it also should determine a new structure in numerous parts of life. The European Council for Rural Law (more usually known as the CEDR from its French name „Comite Européen de Droit Rural"), a think-tank which regularly provides assistance and advice to the institutions of the European Union, also dealt with the cross-border land law issues of the EU; namely, in a commission (COM II) concerning rural areas of the CEDR Congress (Potsdam, 2015) and at the conference on the $60^{\text {th }}$ anniversary of the CEDR (Brussels, 2017). In a Hungarian conference (Budapest, 2017), the legal experts were gathered by the Hungarian Association for Agricultural Law and the Public Law Sub-Commission of the Hungarian Academy of Sciences in order that they could present the possible ways of the improvement for the EU and its Member States. With regard to this development, the present article focuses
\end{abstract}


on the EU's main rules concerning the acquisition of agricultural lands, the infringement procedures against Hungary (hereinafter referred to as Hungarian cases), the report of the European Parliament and the general conclusions of the Budapest conference. The Hungarian cases are relevant not merely for Hungary as the European Commission has expressed its concerns about the most of regulations of the Hungarian land law in comparison with other concerned New Member States. Taking the low numbers of the CJEU cases (concerning land law) into consideration, the Hungarian cases might be significant for the whole of the $E U$ and its future.

Keywords: land law-farmland-agricultural land-acquisition of ownership.

The present article ${ }^{1}$ may be regarded as a continuation of the author's article published in the 4/2016 issue of the Zbornik Radova. ${ }^{2}$ The present article especially focuses on the European challenges which Hungary faced when it adopted new rules connected to the acquisition of the ownership of agricultural lands. In the opinion of the author, the present paper might be interesting for the legal experts in Serbia as well, taking into consideration the topical amendment of the Serbian $^{3}$ land law. ${ }^{4}$

After a short theoretical determination of the so-called 'cross-border acquisition of agricultural lands', the present article particularly deals with the European Union (hereinafter referred to as EU) law and its aspects concerning the cross-border acquisition of agricultural lands. Because of the special importance of the topical infringement procedures launched by the European Commission against Hungary regarding its national land law (hereinafter referred to as the Hungarian cases), the Hungarian cases are analysed in detail as well. Beside infringement procedures at the European Commission and at the Court of Justice of the EU (hereinafter referred to as CJEU), there are also certain preliminary rulings at the CJEU regarding the Hungarian land law. The last event in connection with the Hungarian cases is the publication of the opinion ${ }^{5}$ of the advocate general at the CJEU (hereinafter referred

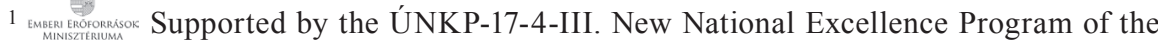
Ministry of Human Capacities.

2 See János Ede Szilágyi, Acquisition of the ownership of agricultural lands in Hungary, taking the EU's and other countries's law into consideration. Zbornik radova Pravnog fakulteta, Novi Sad, 4/2016, 1437-1451.

${ }^{3}$ Cf. Luka Baturan, Economic Analysis of the Ban on Foreigners to Acquiring Property Rights on Agricultural Land in Serbia. Economic of Agriculture, 3/2013, 479-491; Luka Baturan, The ban on Foreigners Acquiring Property Rights on Agricultural and Forest Land in Serbia and Other Regional Countries. Zbornik radova Pravnog fakulteta, Novi Sad, 2/2013, 515-531.

${ }^{4}$ In the present article, land law means the legal provisions of a state which determine the ownership and the use of agricultural and forestry lands.

${ }^{5}$ Joined cases C-52/16 and C-113/16, opinion of advocate general Saugmandsgaard Øe delivered on 31 May 2017. 
to as opinion of advocate general). Although, the opinion of the advocate general does not bind the CJEU in its decisions, it may exert an influence on the final decisions of the CJEU. It is for this reason that the opinion of the advocate general is assessed in the article as well. In 2017, the adoption of the report of the European Parliament concerning farmlands (hereinafter referred to as report of the European Parliament) was an absolute surprise and a real progressive initiative in connection with land law. In a certain sense, it can be regarded as a counter-opinion in connection with the opinion of the advocate general. Therefore the report ${ }^{6}$ of the European Parliament is also detailed in the paper. At the end of this article, some proposals concerning the possible amendment of the EU law are presented. These proposals were determined at a conference organised by the Hungarian Association for Agricultural Law in cooperation with the Public Law Sub-Commission of the Hungarian Academy of Sciences in Budapest in June 2017. The participants and speakers of the conference concentrated on the Hungarian cases, the practice of the European Commission and the report of the European Parliament.

\section{THE THEORETICAL DETERMINATION OF THE SO-CALLED CROSS-BORDER ACQUISITION OF AGRICULTURAL LANDS AND FORESTS IN A GENERAL SENSE AND IN THE EU}

Nowadays, beside inland land transfer, ${ }^{7}$ also cross-border acquisition plays a more and more important role in the ownership and/or the use of agricultural lands and forests (hereinafter together referred to as cross-border acquisition). Nevertheless, it is worth emphasizing that the distinction between internal and cross-border acquisitions cannot be exact. In this paper, in a general sense, cross-border acquisition primarily means the situation in which citizens and legal entities of a country (hereinafter referred to as 'foreigners' or 'investors') gain the ownership or long-term use of an agricultural land or forest situated in another country (hereinafter referred to as 'target' country or area). It is worth emphasizing that the EU law has absolutely different regulatory regimes concerning the ownership of agricultural lands and the usage of agricultural lands. In connection with the EU law, this paper mainly concentrates on the acquisition of the ownership of agricultural lands and forests.

${ }^{6}$ European Parliament, Report on the state of play of farmland concentration in the EU: how to facilitate the access to land for farmers, A8-0119/2017, 30 March 2017.

${ }^{7}$ Cf. Article 4 (1) 1)-n) of Regulation (EU) 1307/2013. According to Article 4 (1) n) of Regulation (EU) 1307/2013, the category of 'transfer' includes also the inheritance as well: “'transfer' means the lease or sale or actual inheritance or anticipated inheritance of land or payment entitlements or any other definitive transfer thereof; it does not cover the reversion of entitlements upon expiry of a lease." 
The goals of the acquisition of agricultural lands can be various: (a) to produce agricultural products, (b) to speculate on the land market, (c) others, (d) the combination of points (a)-(c).

In a wider sense, the situation in which foreigners establish legal entities in the target country and gain the lands of the target country may be regarded as cross-border acquisition as well. In the EU law, this interpretation of a cross-border acquisition could become quite difficult due to the forms of the European Cooperative Society (SCE, namely Societas Cooperativa Europaea) ${ }^{8}$ and the European Company (SE, namely Societas Europaea) ${ }^{9}$. As regards legal entities, there are two elementary issues. First, the traceability of the real ownership (investor) background of the legal entities is always complicated (e.g. difficulties in connection with offshore companies). Second, the number of legal entities might easily be multiplied. The solution of both issues is tightly connected to the proper registration of the affected legal entities and their investors (ownership background). Otherwise, it is worth noticing that in the EU law, the 'cross-border' element with regard to land acquisitions is typically assessed in the procedure of the CJEU.

\section{THE EUROPEAN UNION LAW CONCERNING THE CROSS-BORDER ACQUISITION OF THE OWNERSHIP OF AGRICULTURAL LANDS}

The EU law does not prohibit Member State measures restricting the acquisition of agricultural lands by entities from outside of the EU or the European Economic Area (EEA). Nonetheless, inside the EU and the EEA, the EU law, on the one hand, requires the implementation of the four EU freedoms of the internal market (in connection with the acquisition of agricultural lands, the free movement of persons and capital are applicable) and, on the other hand, it prohibits the discrimination on the basis of nationality. ${ }^{10}$ In connection with the interpretation of these rules, Csák-Kocsis-Raisz emphasize that "EU Laws do not regulate the ownership of agricultural land directly, however, the judicial practice formed by the principles of the Treaty on the Functioning of the European Union (TFEU) sets frames and orientations for the legislation and implementation of laws." 11

${ }^{8}$ Council regulation (EC) No 1435/2003 on the Statute for a European Cooperative Society (SCE).

${ }^{9}$ Council regulation (EC) No 2157/2001 on the Statute for a European company (SE).

${ }^{10}$ Ágoston Korom, A termőföldek külföldiek általi vásárlására vonatkozó 'moratórium' lejártát követően milyen birtokpolitikát tesz lehetővé a közösségi jog. Európai Jog, 6/2013, 7-16.

${ }^{11}$ Csilla Csák - Bianka Kocsis - Aniko Raisz, Vectors and indicators of agricultural policy and law from the point of view of the agricultural land sector. Journal of Agricultural and Environmental Law (JAEL), 19/2015, 38. 
The concerned rules of the Treaty on the Functioning of the European Union (TFEU) are especially the free movement of persons and capital ${ }^{12}$ (Articles 49 and 63 of the TFEU; hereinafter referred to as 'negative integration rules' or 'negative integration model') and an objective ("to ensure a fair standard of living for the agricultural community") of the Common Agricultural Policy (CAP) of the EU (i.e. Article 39 (1) point b) of the TFEU; hereinafter referred to as 'positive integration rules' or 'positive integration model'). ${ }^{13}$ According to Ágoston Korom, ${ }^{14}$ beside the anti-discrimination rules, the EU law determines the competence of its Member States to adopt their national land law in the intersection of the negative and positive integration rules. The mentioned TFEU rules contain rather general provisions, therefore, the CJEU has an important role to interpret them and to help assess the national land laws of the Member States. ${ }^{15}$ As regards the negative integration rules, according to the practice of the CJEU, full compliance with the EU law can be ensured by the national law (a) if the public interest is pursued by the national law (i.e. objectives in the public interest) and (b) if the measure of the national law cannot be exchanged for less restrictive measures (i.e. the principle of proportionality). As regards the objectives in the public interest, the CJEU regards the objectives of national agricultural land policy such as (a1) to preserve a permanent agricultural community, (a2) that the land should belong to persons wishing (and being capable) to farm it, (a3) the possibility to counteract speculative land acquisition, (a4) etc. to be conform with the TFEU and to pursue an objective in the public interest. The restrictive measures accepted by the jurisdiction of the CJEU are (b1) the procedure of prior authorisation for the acquisition of agricultural land, ${ }^{16}$ (b2) the system of prior declaration, ${ }^{17}$ (b3) the provision for a higher tax on the resale of land occurring shortly after acquisition, ${ }^{18}$ (b4) the requirement of a substantial minimum duration for leases of agricultural land, ${ }^{19}$ (b5) etc.

${ }^{12}$ It is worth noticing that, according to Annex I of Council directive 88/361/EEC, investments in real estate on national territory by non-residents are part of the capital movements in the EU.

${ }^{13}$ About distinction between the negative and positive integration models and rules of the EU, see Ágoston Korom, Az új földtörvény az uniós jog tükrében, in: Az új magyar földforgalmi szabályozás az uniós jogban (ed.: Ágoston Korom), Nemzeti Közszolgálati Egyetem, Budapest, 2013, 14.

${ }^{14}$ Korom (2013), 14.

15 See furthermore János Ede Szilágyi, The Accession Treaties of the New Member States and the national legislations, particularly the Hungarian law, concerning the ownership of agricultural land. JAEL, 9/2010, 52-55.

${ }^{16}$ See Case C-213/04 Ewald Burtscher v Josef Stauderer [2005] ECR I-10309, paragraph 57; and Case C-452/01, paragraphs 41-45.

${ }^{17}$ See Case C-213/04, paragraphs 44, 52-54, 59-62.

${ }_{18}$ See Case C-370/05, paragraph 39.

${ }^{19}$ See Case C-370/05, paragraph 39. 


\subsection{The discrimination and the European Commission's infringement procedures against the New Member States}

The present article tries to find an answer to the question whether the EU Commission's investigation regarding the land law of the New Member States may be considered discriminatory or not.

The antecedents of the European Commission's infringement procedures against the New Member States are the followings. At the time of their accessions, on the basis of their Accession Treaties of 2003, 2005 and 2012, (since 2004) the Czech Republic, Estonia, Latvia, Lithuania, Hungary, Poland, Slovakia, (since 2007) Romania, Bulgaria and (since 2013) Croatia (i.e. the New Member States) were each granted a transitional period ${ }^{20}$ for maintaining existing legislation restricting the acquisition of the ownership ${ }^{21}$ of agricultural lands and forests, by derogation from the freedom of capital movements. After the transitional period had expired, numerous new Member States adopted new land laws including restrictive measures. Typically, the legislation of Old Member States provided a role model for the New Member States (the French and Austrian models were quite popular among them). In 2015, the EU Commission launched infringement procedures against some of the New Member States; namely Bulgaria, Hungary, Latvia, Lithuania and Slovakia. In the opinion of the European Commission, some provisions of these Member States may be considered as the violation of the free movement of capital and the freedom of establishment, and, therefore, this situation discourages cross-border investment in the land market of the New Member States.

In connection with these measures of the European Commission, the CEDR Congress COM II Conclusion noted: "In cases when the EU Commission initiated infringement proceedings against the New Member States because of such Member State-restrictions that already exist in Old Member States, the action of the EU Commission can raise concerns, and may be regarded discriminative". ${ }^{22}$ Some representatives of the European Parliament interpreted the situation similarly, therefore they raised several questions in their so-called 'questions for written answer to the Commission'. ${ }^{23}$ Namely, for example: "Given the Commission's

${ }^{20}$ In connection with the transitional period, László Fodor expressed a quite critical opinion. In his opinion, it is a double standard applied against the new member states. Its pseudolatry nature is hidden among other things that the subsidies given to equalize the price of the lands during these 7 years were much lower than had been for the earlier member states; László Fodor, Kis hazai földjogi szemle 2010-ből, in: Az európai földszabályozás aktuális kihívásai (ed.: Csák Csilla), Novotni Alapítvány, Miskolc, 2010, 124.

${ }^{21}$ Namely, there are generally no restrictions on the lease of agricultural lands by foreigners.

22 Published by János Ede Szilágyi, Conclusions, JAEL, 19/2015, 92 (this part of the Conclusions was adopted).

${ }^{23}$ See: Question for written answer to the Commission by Norbert Erdös, Infringement proceedings relating to landholding policy in the new Member States, P-005558-15, 8 April 2015; Question for written answer to the Commission by Norbert Erdös, Legal effect of the accession 
discretionary scope regarding the launch of infringement proceedings, does the Commission consider that this situation is compatible with the fundamental principle of equal treatment - which is also applied in EC law - and with the provisions on the prohibition of discrimination laid down in the Commission's Code of Good Administrative Behaviour?" 24 In its answer, the European Commission referred to the end of the transitional period provided in the Accession Treaties of the New Member States as a rightful reason to launch infringement procedures merely against the New Member States: "The current systematic check of agricultural laws by the Commission in six countries has its roots in the Treaties of Accession, whereby these countries were granted temporary derogations from the free movement of capital for agricultural land. With the expiry of these derogations in 2014, Member States had to check the restrictions for investments from other EU Member States on their land markets against the justification criteria as set out in the Treaty on the Functioning of the European Union and against the principle of proportionality. ... The Commission has carried out an assessment of these new land laws and has opened infringement procedures against the countries where the rules are not in line with EC law." 25 The answer of the European Commission raised the question whether the expiry of these derogations provide a lawful title to assess only the New Member States' land law. Taking the answers of the European Commission into consideration, Ágoston Korom noted that the European Commission could not reassuringly prove its right to assess only the New Member States' national land laws on the basis of the expiry of derogations. Citing the answers of the European Commission, Korom also drew the attention to the situation that the European Commission's standard practice could not prove such a doubtful Commission's procedure either. ${ }^{26}$ Essentially, Ildikó Bartha also made a similar conclusion with regard to the answers of the European Commission. ${ }^{27}$ The opinion of the author of the present paper is that although Korom's interpretation is quite vigorous, he could not find either a justified and reasonable legal title for the European Commission (in its answers) to confirm its right to assess the EU-law-conformity of national land laws merely in connection with the New Member States.

treaties of the new Member States, E-013450-15, 2 October 2015; Question for written answer to the Commission by Norbert Erdős, Equal treatment among the Member States in the area of property policy, E-002940-16, 12 April 2016; etc.

${ }^{24}$ Question for written answer to the Commission by Pál Csáky, Application of the fundamental principle of equal treatment, E-013351-15, 30 September 2015.

${ }^{25}$ Answer given by Lord Hill on behalf of the Commission, P-005558/2015, 13 May 2015.

26 Ágoston Korom, Gondolatok az új tagállamok birtokpolitikájával kapcsolatban transzparencia és egyenlő elbánás, in: Honori et Virtuti (ed.: Gellén Klára), Pólay Elemér Alapítvány, Szeged, 2017, 264.

${ }^{27}$ Ildikó Bartha, Földindulás - A földforgalom-szabályozás tagállami és uniós joga. Jogtudományi Közlöny, 9/2017, in press. 


\subsection{The Hungarian cases and the opinion of advocate general}

At the time of the expiry of the transitional period, the Hungarian legislator had to reassess the national land law regime (which was highly analysed and presented by numerous authors; e.g. Csák, ${ }^{28}$ Nagy, ${ }^{29}$ Prugberger, ${ }^{30}$ Tanka $^{31}$ ), and adopted an absolutely new one (which was outstandingly analysed and presented by numerous authors; e.g. Bányai, ${ }^{32}$ Bobvos, ${ }^{33}$ Csák,${ }^{34}$ Hornyák, ${ }^{35}$ Kurucz, ${ }^{36}$ Nagy, ${ }^{37}$ Olajos $^{38}$ ) in and after 2013. However, numerous aspects of the new Hungarian

${ }^{28}$ Csilla Csák perspicaciously analysed the previous Hungarian land law regime in respect of the EU law: Csák Csilla, Die ungarische Regulierung der Eigentums- und Nutzungsverhältnisse des Ackerbodens nach dem Beitritt zur Europäischen Union. JAEL, 5/2010, 20-31.

${ }^{29}$ Beside the land law regime other legal fields play an important role, for example within the regulatory framework of financial law the tax regulation as it was pointed out by Zoltán Nagy: Csilla Csák, Zoltán Nagy, Regulation of obligation of use regarding the agricultural land in Hungary. Zbornik radova Pravnog fakulteta, Novi Sad, 2/2011, 541-550; and Zoltán Nagy, A termőfölddel kapcsolatos szabályozás pénzügyi jogi aspektusai, in: Az európai földszabályozás aktuális kihívásai (ed.: Csák Csilla), Miskolc, Novotni Kiadó, Miskolc, 2010, 187-198.

${ }^{30}$ Tamás Prugberger, Szempontok az új földtörvény vitaanyagának értékeléséhez és a földtörvény újra kodifikációjához. Кapu, 6-7/2012, 62-65.

${ }^{31}$ Endre Tanka, Nem én kiáltok, a föld dübörög, Kairosz, Budapest, 2011.

32 Krisztina Bányai, Theoretical and practical issues of restrains of land acquisition in Hungary. JAEL, 20/2016, 5-15.

${ }^{33}$ Pál Bobvos, Erika Farkas Csamangó, Péter Hegyes, Péter Jani, A mező- és erdőgazdasági földek alapjogi védelme, in: Számadás az Alaptörvényröl (ed.: Balogh Elemér), Magyar Közlöny Lap- és Könyvkiadó, Budapest, 2016, 31-40.

${ }^{34}$ Csilla Csák, Zsófia Hornyák, Bianka Kocsis, The altering Hungarian regulation of transactions in agricultural lands, in: Current questions and european answers on the field of law and justice in Romania and Hungary (ed.: Christian Dumiriu Mihes, Diana Cirmaciu), Editura Pro Universitaria, Bucuresti, 2016, 86-94.

${ }^{35}$ Zsófia Hornyák prudently drew the attention to the importance of a new succession regime concerning agricultural law: Zsófia Hornyák, Die Regeln der Erbfolge auf der Basis einer Verfügung von Todes wegen im landwirtschaftlichen Grundstückverkehr. JAEL, 21/2016, 4-16. Previously, she comprehendingly assessed the relationship between the Swiss, the Austrian and the (new) Hungarian land regime: Zsófia Hornyák, Die Voraussetzungen und die Beschränkungen des landwirtschaftlichen Grunderwerbes in rechtsvergleichender Analyse. CEDR Journal of Rural Law, 1/2015, 88-97.

${ }^{36}$ Mihály Kurucz, Gondolatok a magyar földforgalmi törvény uniós feszültségpontjainak kérdéseiröl, in: A Magyar Tudomány Napja a Délvidéken 2014 (ed.: József Szalma), VMTT, Novi Sad, 2015, 120-173.

${ }^{37}$ Zoltán Nagy and his company rationally presented the new legislation in a general sense: Klaudia Holló, Zsófia Hornyák, Zoltán Nagy, Die Entwicklung des Agrarrechts in Ungarn zwischen 2013 und 2015. JAEL, 19/2015, 56-64.

${ }^{38}$ István Olajos and Szabolcs Szilágyi analysed the new legislation in a general sense: István Olajos, Szabolcs Szilágyi, The most important changes in the field of agricultural law in Hungary between 2011 and 2013. JAEL, 15/2013, 93-110. István Olajos exceedingly presented the first judgements of the Hungarian Constitutional Court: István Olajos, Die Entscheidung des Verfassungsgerichts über die Rolle, die Entscheidungen und die Begründetheit der Gründen der Stellungnahmen der örtlichen Grundverkehrskommissionen. Agrar-und Umweltrecht, 8/2017, 
land regime were contested by the European Commission and even by private persons. These disputes resulted in the different cases. The European Commission launched two infringement procedures against Hungary. Besides, private persons also sued the Hungarian authorities in connection with the new law at the Hungarian courts (e.g. in Szombathely), ${ }^{39}$ and, after that, the Hungarian courts submitted requests for a preliminary ruling.

As far as the infringement procedures are concerned, one of them is a general and comprehensive infringement procedure, as the European Commission assessed the new Hungarian land law regime as a whole in detail (hereinafter referred to as comprehensive infringement procedure). Besides, there is a special infringement procedure as well, which concerns national transitional rules on usufruct (hereinafter referred to as usufruct infringement procedure). As to the comprehensive infringement procedure, this legal case was perfectly presented by Tamás Andréka and István Olajos. ${ }^{40}$ "In the comprehensive case, the EU Commission launched its so-called pilot procedure with regard to certain legal institutions which were later, during the negotiations with the Hungarian government found to be in compliance with the EU regulations. Such EU-conform legal institutions are (a) the procedural role of local commission, (b) land acquisition limit of farmers and land possession limit of farmers and agricultural producer organizations, (c) the system of pre-emption right and the right of first refusal, and (d) the regulation on the term of leasehold. The even presently going infringement procedures, the following national measures' compliance are questioned by the Commission: (a) complete ban on the acquisition of land by domestic and foreign legal entities, (b) proper degree in agricultural or forestry activities, (c) proper agricultural or forestry practice abroad, (d) obligation on the buyer to farm the land himself, (e) impartiality in prior authorisation for the sale of lands. Among the questioned institutions, the ban on legal entities is the bone of the present land acquisition regime, and, according to Tamás Andréka and István Olajos, the aim of this institution is to avoid the uncontrollable chain of ownership which would be in contradiction with keeping the population preserving ability of the country, since it would be impossible to check land maximum and the other acquisition limits." $" 1$

284-291. István Olajos focused on the practical dimensions of the new Hungarian land regime and outstandingly concentrated on the most controversial issues of them: István Olajos, Földjogi kiskáté. Miskolci Jogi Szemle, spec. ed. 2/2017, 409-417.

${ }^{39}$ First, Anikó Raisz drew the attention to the importance of the Szombathely cases; see Anikó Raisz, Topical issues of the Hungarian land-transfer law. CEDR Journal of Rural Law, 1/2017, 74 .

${ }^{40}$ Tamás Andréka - István Olajos, A földforgalmi jogalkotás és jogalkalmazás végrehajtása kapcsán felmerült jogi problémák elemzése. Magyar Jog, 7-8/2017, 422-424.

${ }^{41}$ The thoughts of Andréka and Olajos were summarized and translated by: Anikó Raisz, Topical issues of the Hungarian land-transfer law. CEDR Journal of Rural Law, 1/2017, 74. 
As for the usufruct infringement procedure, the subject of this case has numerous similarities with the preliminary ruling mentioned above. Because of the released opinion of the advocate general in connection with the preliminary ruling (i.e. the preliminary ruling is in an advanced status in comparison with the usufruct infringement procedure), the paper presents the essential aspects of the legal background of these cases (i.e. the usufruct infringement procedure and the Szombathely case) under the details of the preliminary ruling. According to the controversial transitional rules of Hungary, the concerned Hungarian authorities had to cancel the registration in the property register of the usufructuary rights in agricultural land on the basis of a national legislation prescribing the extinction of the usufructuary rights and rights of use in productive land in the absence of proof that those rights were created between close members of the same family. According to the opinion of the advocate general, the advocate general considered that the "legislation and the cancellation decisions taken on the basis thereof are contrary to the free movement of capital. In fact, the requirement that such rights must have been created between close members of the same family gives rise to effects which are indirectly discriminatory against nationals of other Member States and cannot be justified by any of objectives put forward by the Hungarian Government." $"$ "In my opinion, the most interesting aspects of the opinion are the followings.

First, the advocate general merely referred to the 'negative integration rules' of the TFEU, and the advocate general did not take the 'positive integration rules' into consideration. According to my interpretation, this argument of the advocate general considered agricultural land as merely an economic good, and considered the acquisition of agricultural lands only as a commercial issue. In the opinion of Tamás Andréka, if the interpretation of the CJEU in connection with the EU law's aspects of cross-border acquisition moves toward this excessively negative integration model as well, all EU countries which apply restrictions on the land market will be forced to cancel their land-market measures in ten years. ${ }^{43}$

Second, the opinion of the advocate general interpreted the Hungarian national rules concerning usufructuary rights as a simple lease contract. Namely, the specialities of the usufruct were absolutely neglected, or the legal substances of the usufruct and the lease were confused in the opinion. That is the reason why the advocate general's arguments concerning the existence of indirect discrimination are quite unjustified and unreasonable. In Hungary, the typical parties of a usufructuary right are relatives. However, the advocate general interpreted this speciality of the usufruct as a condition which does not establish a formal distinc-

\footnotetext{
42 Joined cases C-52/16 and C-113/16, opinion of advocate general Saugmandsgaard Øe delivered on 31 May 2017, para. 4.

${ }^{43}$ Tamás Andréka opinion was communicated at the Conference of the Hungarian Association for Agricultural Law in Budapest on 1 June 2017.
} 
tion by reference to origin, nevertheless, it is more easily satisfied by nationals of Hungary than by those of other Member States. ${ }^{44}$

\subsection{The report of the European Parliament}

As opposed to the advocate general's opinion presenting an excessively negative integration model (i.e. agricultural lands are merely economic goods), the European Parliament adopted a report representing the positive integration model after certain antecedent. ${ }^{45}$ Answering the aforementioned, as well as having regard to the infringement proceedings against the New Member States, on 27 th April 2017 the European Parliament adopted the report ${ }^{46}$ on farmland concentration. The European Parliament warns of the phenomenon of land grabbing ${ }^{47}$ in the EU. ${ }^{48}$ Besides, the EP took into consideration the followings in the report: (a) "land is on the one hand property, on the other a public asset, and is subject to social obligations",49 (b) "land is an increasingly scarce resource, which is non-renewable, and is the basis of the human right to healthy and sufficient food, and of many ecosystem services vital to survival, and should therefore not be treated as an ordinary item of merchandise"; 50 (c) "sufficient market transparency is essential... and should also extend to the activities of institutions active on the land market"51; (d) "the sale of land to non-agricultural investors and holding companies is an urgent problem throughout the Union, and whereas, following the expiry of the moratoriums on the sale of land to foreigners, especially the new Member States have faced particularly strong pressures to amend their legislation,

${ }^{44}$ Joined cases C-52/16 and C-113/16, opinion of advocate general Saugmandsgaard Øe delivered on 31 May 2017, para. 71-81.

45 János Ede Szilágyi, Anikó Raisz, Bianka Kocsis, New dimensions of the Hungarian agricultural law in respect of food sovereignty. JAEL, 22/2017, in press.

${ }^{46}$ European Parliament, Report on the state of play of farmland concentration in the EU: how to facilitate the access to land for farmers, Committee on Agriculture and Rural Development A8-0119/2017, 30.03.2017 (hereinafter referred to as EP 2007).

${ }^{47}$ Definition of land grabbing according to the European Economic and Social Committee: „There is no internationally recognised single definition of land grabbing. Land grabbing is generally understood to mean a process of large-scale acquisition of agricultural land without consulting the local population beforehand or obtaining its consent. Ultimately, this diminishes the scope of the local population to manage a farm independently and to produce food. The owner also has the right to use the resources (land, water, forest) and the profits arising from their use. This can lead to a situation in which established agricultural land use is abandoned in favour of other activities; European Economic and Social Committee: Opinion: Land grabbing - a warning for Europe and a threat to family farming, NAT/632 - EESC-2014-00926-00-00-AC-TRA (EN), Brussels, 21 January 2015, 2.2.

${ }^{48}$ EP 2017, point AM and page 14.

${ }^{49}$ EP 2017, point G.

${ }^{50} \mathrm{EP} 2017$, point $\mathrm{J}$.

${ }^{51}$ EP 2017, point $P$. 
as comparatively low land prices have accelerated the sale of farmland to large investors"; 52 (e) "farmland areas used for smallholder farming are particularly important for water management and the climate, the carbon budget and the production of healthy food"; 53 (f) "there is a substantial imbalance in the distribution of high-quality farmland, and whereas such land is decisive for the quality of food, food security and people's wellbeing"; 54 (g) "small and medium-sized farms, distributed ownership or properly regulated tenancy, and access to common land... encourage people to remain in rural areas and enable them to work there, which has a positive impact on the socio-economic infrastructure of rural areas, food security, food sovereignty and the preservation of the rural way of life"; 55 (h) "farmland prices and rents have in many regions risen to a level encouraging financial speculation, making it economically impossible for many farms to hold on to rented land or to acquire the additional land needed to keep small and medium-sized farms viable"; 56 (i) "differences among the Member States in farmland prices further accentuate concentration processes"; $57(\mathrm{j})$ there are numerous findings concerning speculations ${ }^{58}$ and abuse ${ }^{59} ;(\mathrm{k})$ "limited companies are moving into farming at an alarming speed; whereas these companies often operate across borders, and often have business models guided far more by interest in land speculation than in agricultural production". ${ }^{60}$

With regard to the abovementioned, the EP (a) "recognises the importance of small-scale family farms for rural life", ${ }^{61}$ and "considers that local communities should be involved in decisions on land use". ${ }^{2}$ (b) The European Parliament "calls for farmland to be given special protection with a view to allowing the Member States, in coordination with local authorities and farmers' organisations, to regulate

52 EP 2017, point Q.

${ }^{53}$ EP 2017, point S.

${ }^{54}$ EP 2017, point T.

${ }^{55}$ EP 2017, point V.

${ }^{56}$ EP 2017, point AB.

${ }^{57}$ EP 2017, point AC.

58 "the purchase of farmland has been seen as a safe investment in many Member States, particularly since the 2007 financial and economic crisis; whereas farmland has been bought up in alarming quantities by non-agricultural investors and financial speculators"; EP 2017, point $\mathrm{AJ}$; and "the creation of speculative bubbles on farmland markets has serious consequences for farming, and whereas speculation in commodities on futures exchanges drives up farmland prices further"; EP 2017, point AL.

59 "a number of Member States have adopted regulatory measures to protect their arable land from being purchased by investors; whereas cases of fraud have been recorded in the form of land purchases involving the use of 'pocket contracts', in which the date of the conclusion of the contract is falsified; whereas, at the same time, large amount of land has been acquired by investors"; EP 2017, point AK.

${ }^{60}$ EP 2017, point AQ.

${ }^{61}$ EP 2017, point 14.

${ }^{62}$ EP 2017, point 18. 
the sale, use and lease of agricultural land in order to ensure food security...". ${ }^{63}$ (c) Furthermore, the European Parliament - among others - calls on (c1) "the Commission to establish an observatory service for the collection of information and data on the level of farmland concentration and tenure throughout the Union"; 64 (c2) "the Commission, on this basis, to report at regular intervals to the Council and Parliament on the situation regarding land use and on the structure, prices and national policies and laws on the ownership and renting of farmland, and to report to the Committee on World Food Security (CFS)...". ${ }^{55}$

The report of the European Parliament proves that the positive integration model also has an importance for the whole of the European Union and not only for the New Member States.

\subsection{The possible reforms of the $E U$ law concerning the cross-border acquisition of the ownership of agricultural lands}

Stimulated by the uncertainties observed in connection with the EU law concerning acquisition of agricultural lands, the COM II's general reporter (János Ede Szilágyi) of the CEDR Congress submitted a proposal in which the possible ways of the EU law's improvement were formally analysed. According to the Conclusions of the COM II, "The question may be solved in different ways; here, we draw the attention to four possible solutions: [a] The EU ceases to apply the four fundamental freedoms with regard to the land policy of the MSs. This step would mean in a way the easing of the integration. [b] Those MSs which introduced restrictions in their land market, liberalize the rules of their land market or introduce more liberal rules. Obviously, this may severely hurt the interests of the citizens of these MSs, and may lead to land-grabbing with regard to the land markets of the new MSs. [c] The debate may be solved in a simple political way: i.e. the case may be forgotten, e.g. based on a political background-deal. In this case, there is no guarantee that the question would not arise later again, or that someone (basically anyone) does not bring the question in front of the CJEU in the frame of a preliminary procedure, basically circumventing the background-deal of the politicians (i.e. of the EU Commission and the given MSs). [d] We move in the direction of further regulation, even modifying the primary legislation of the $E U$ if necessary. This may cease the uncertainty and deepen the integration; on the other hand, it may be interpreted as giving up a certain part of the sovereignty." 66 In an unaccepted part of the Conclusions of the COM II, the general reporter

${ }^{63}$ EP 2017, point 38 .

${ }^{64}$ EP 2017, point 2.

${ }^{65}$ EP 2017, point 8.

${ }^{66}$ Published by János Ede Szilágyi, Conclusions. JAEL, 19/2015, 93 (this part of the Conclusions was adopted). 
elaborated a possible way how to develop the EU legislation toward the positive integration model. In the opinion of the general reporter, the agricultural land is not a typical object of a commercial transaction, and, therefore, the principles of the freedom of the capital and of the free movement of persons shall not apply without restrictions in the case of agricultural land. For providing this special status of agricultural lands, the general reporter could imagine the amendment of the EU legislation (even of the Treaties of the EU). Otherwise, the general reporter would provide a liberty for the Member States whether they endeavour to apply special rules in the transaction of agricultural lands or not. The general reporter would detail the definition of the 'agro-productional use of agricultural lands' and the admissible public interest objectives which can be called up when restricting the free movement of capital and persons with regard to agricultural lands. The general reporter would also regulate more precisely the applicable measures which may be considered as proportional restrictions. Among these measures, the general reporter would pay a special attention to the regulations concerning the acquisitions by legal entities. ${ }^{67}$

Inspired by the adoption of the report of the European Parliament, the participants of a conference organised by the Hungarian Association for Agricultural Law in cooperation with the Public Law Sub-Commission of the Hungarian Academy of Sciences (Budapest, 2017) also dealt with the possible development opportunities of the EU law concerning the acquisition of agricultural lands (especially the ownership-acquisition). Mihály Kurucz determined several conceptions how to amend the EU law in order that the EU can fulfil the objectives defined in the report of the European Parliament. One of these concepts is about the renationalization of the Common Agricultural Policy of the EU. According to this concept, Member States could regain their absolute competence and freedom to regulate their own land market in exchange for the EU agricultural and rural development financial supports (i.e. the Member States would lose these supports). His other concept would handle the situation, beyond the negative integration rules of the $\mathrm{EU}$, via stricter rural development and environmental protection regulations adopted by the EU. It could be a smart indirect regulation in connection with the land transfer. Tamás Andréka also proposed more concepts. One of them is a remarkable movement from the free movement of capital towards the right of establishment. According to another Andréka's concept, EU legislators should integrate land-acquisition into the Common Agricultural Policy. The concept of Ágoston Korom is not a real concept of the amendment of the EU law. Namely, in the opinion of Korom, the present legal framework of the EU is acceptable, nevertheless, the European jurisprudence should rethink the scientific background of the

${ }^{67}$ Published by János Ede Szilágyi, Conclusions. JAEL, 19/2015, 94-95 (this part of the Conclusions was not adopted). 
issue, create a new system and communicate this to the European Commission. In my opinion, the Comprehensive Economic and Trade Agreement (CETA) also contains a useful solution. Namely, the scope of the CETA extends to the transfer of agricultural lands as well, and therefore the CETA rules concerning investments (e.g. market access, national investment) are applicable to the acquisition of agricultural lands. Despite this scope of the CETA, the parties (i.e. the concerned countries, e.g. the Member States of the EU) have the right to take reservations concerning cross-border acquisition of agricultural lands. It means that countries may maintain their existing measures, and - in certain cases - adopt new or more restrictive measures that are not conform with the CETA rules (e.g. Hungary took these kinds of reservations). Accordingly, the CETA's reservation-mechanism could also be used in the EU law.

\section{Conclusions}

In my opinion, the abovementioned situation proves that the EU law concerning cross-border acquisition of agricultural lands and the related jurisdiction of the CJEU are not static phenomena. The Member States of the EU have the competence to constitute their national land law regimes in a dynamically changing frame of the EU law. Finally, the Member States have to equilibrate between the positive and negative integration models of the EU law. Nevertheless, the report of the European Parliament created a new situation in the uncertainties, and it can be regarded as an explicit step toward the positive integration model. 
Szilágyi János Ede, Ph.D., egyetemi docens Miskolci Egyetem Állam és Jogtudományi Kar civdrede@uni-miskolc.hu

\section{Határon átívelő tulajdonszerzés termőföldön és egyes időszerü kérdések a magyar jogban}

Összefoglaló: Miközben Szerbia az unióhoz történö felzárkózása miatt éppen arra törekszik, hogy földjogát EU-konformmá tegye, látni kell azt, hogy maga az EU joga sem statikus a határon átnyúló földszerzések vonatkozásában. A kérdéskör ugyanis nagyon is aktuális az EU-n belül. Ezt támasztja alá az, hogy az Európai Bizottság tömegesen inditott kötelezettségszegési eljárásokat a 2004-ben illetve az azt követöen csatlakozott tagállamokkal (új tagállamok) szemben. Tévedés ugyanakkor azt hinni, hogy ezen ügyek pusztán az új tagállamok problémái lennének, és hogy a többi, régi tagállam esetén immáron nincsenek is kérdések. Ezt támasztja alá az Európai Parlament 2017-es jelentése is a földkoncentráció tárgyában. Úgy tünik tehát, hogy a napjainkban több ponton is reformra szoruló Európai Unió a földjog, különösen annak határon átnyúló aspektusai vonatkozásában is újragondolást érdemel. A kérdéssel foglalkozott az Európai Agrárjogi Tanács is, amely az EU szerveinek tanácsadó testülete. Így a CEDR 2015-ös potsdami kongresszusának II. munkabizottságában a vidéki területek kapcsán, illetve a CEDR 60. évfordulóján. Magyarországon a szakértök pedig 2017-ben azért gyültek össze, hogy - több más mellett - vázolják egy lehetséges továbblépés lehetöségeit. Jelen cikk e folyamatokhoz illeszkedve mutatja be az EU jogának földszerzésekre vonatkozó föbb elöirásait, a magyar kötelezettségszegési eljárásokat, az Európai Parlament jelentését, és a budapesti konferencia legföbb felvetéseit. A magyar ügyek nem csak Magyarország számára birnak jelentöséggel, ugyanis a magyar földjog az, amely kapcsán a legtöbb aggodalmat fogalmazott meg az Európai Bizottság. Vagyis a magyar ügyek igencsak lényegesek az egész Európai Unió joga és jövője szempontjából.

Kulcsszavak: földjog - mezögazdasági földek - tulajdonszerzés. 
Др Јаноми Еде Силађи, ванредни иррофесор

Универзииеети у Мищколиу

Правни факулиетеи

civdrede@uni-miskolc.hu

\section{Прекогранично стицање својине на пољопривредном земљишту и поједини проблеми мађарског права с тим у вези}

Сажетиак: Будући да Србија ради на усклађивању својих йройиса о

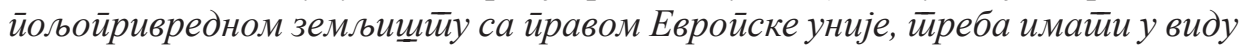
да йраво Евройске уније у вези са йрекогрраничним сиичиањем йољойривредног земљищйа није стиайичан феномен. Наиме, реч је о йроблему који је йоирилично конйроверзан међу инстиитуцијама и државама чланицама Евройске уније. О овоме сведочи значајан број йостиуйака йо йужби због неисйуњења обавеза које Евройске комисије йокреће йройив држава чланица које су Евройској унији иристиуйле йочев од 2004. г̄одине (у даљем раду означене

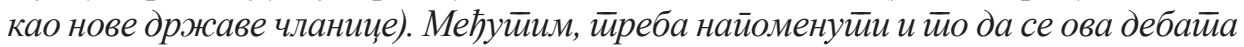
не тииче искључиво нових држава чланииа, нег̄о је ойщйијег̄ каракиетера, јер

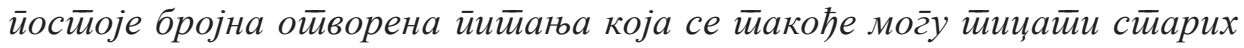
држава чланииа. То је разлог̄ (или један од најисииакнуйијих разлог̄a) због̄ ког̄

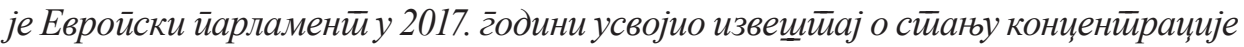
йољойривредних йоврщина у Евройској унији. Делује да су йроблеми у вези са земљишиеме добили на значају у Евройској унији, шиио се може довестии у везу са чињенииом да је Евройска уније у својеврсној кризи. Она би тиребало да редефинище своју орг̄анизаиију, иилеве и, йоврх йог̄a, да друг̄ачије уреди

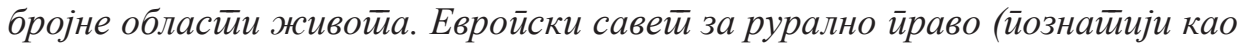
CEDR йо франиуском називу Comité Européen de Droit Rural) је својеврсна

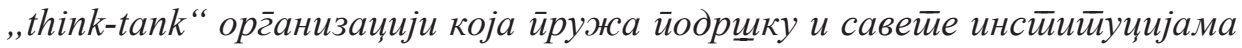
Евройске уније. Она се између остиалог̄, бави и иреког̄раничним асиеекииима землищног̄ иррава на нивоу Евройске уније. То је, йре свег̄а дощло до изражаја на конгрресу одржаном у Пойсдаму 2015. гоодине и конференцији одржаној у Бриселу 2017. гоодине йоводом щездесейог̄одищњице CEDR. На мађарској конференцији која је 2017. гордие одржана у Будимиешитии, окуйили су се ексиертии мађарског̄ Удружена за йољойривредно йраво и ирредстиавниии мађарске Академије наука задужени за области јавног̄ иррава у иилу иредстиављања могуућих йобољщиња за Евройску унију и њене државе чланице. С йим у вези, у чланку су иредстиављена основна йравила у вези са стиицањем йољоиривредног земљищйа, йостиуйак йо йужби због неисиуюења обавеза ирротив Мађарске (у даљем раду означени као мађарски случајеви), извешийај 


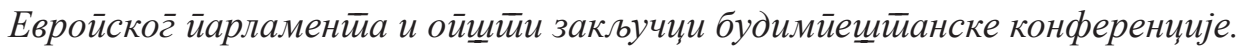
Мађарски случајеви нису битини само за Мађарску, будући да је Евройска

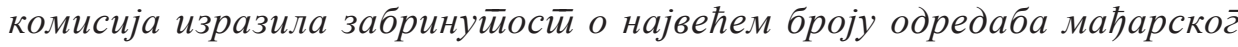
земљищног̄ ирава које су иоознаиее и у осйалим новим државама чланицама. Имајући у виду мали број случајева у вези са землищним ирравом који су до сада били расирављени ирред Судом ирравде Евройске уније, мађарски случајеви би моглли битии од значаја за целу Евройску унију и њену будућносии.

Кључне речи: земљищно ирраво - иољойривредно земљищйе - сииицање својине.

Датум пријема рада: 18.09.2017. 